\title{
Melanin-Concentrating Hormone Neurons Release Glutamate for Feedforward Inhibition of the Lateral Septum
}

\author{
Melissa J.S. Chee, ${ }^{1}$ Elda Arrigoni, ${ }^{2}$ and Eleftheria Maratos-Flier ${ }^{1}$ \\ ${ }^{1}$ Division of Endocrinology and ${ }^{2}$ Department of Neurology, Beth Israel Deaconess Medical Center, Boston, Massachusetts 02115
}

\begin{abstract}
Melanin-concentrating hormone $(\mathrm{MCH})$ regulates vital physiological functions, including energy balance and sleep. $\mathrm{MCH}$ cells are thought to be GABAergic, releasing GABA to inhibit downstream targets. However, there is little experimental support for this paradigm. To better understand the synaptic mechanisms of mouse $\mathrm{MCH}$ neurons, we performed neuroanatomical mapping and characterization followed by optogenetics to test their functional connectivity at downstream targets. Synaptophysin-mediated projection mapping showed that the lateral septal nucleus (LS) contained the densest accumulation of MCH nerve terminals. We then expressed channelrhodopsin-2 in $\mathrm{MCH}$ neurons and photostimulated $\mathrm{MCH}$ projections to determine their effect on LS activity. Photostimulation of MCH projections evoked a monosynaptic glutamate release in the LS. Interestingly, this led to a feedforward inhibition that depressed LS firing by a robust secondary GABA release. This study presents a circuit analysis between MCH and LS neurons and confirms their functional connection via monosynaptic and polysynaptic pathways. Our findings indicate that MCH neurons are not exclusively GABAergic and reveal a glutamate-mediated, feedforward mechanism that inhibits LS cells.
\end{abstract}

Key words: electrophysiology; glutamate; hypothalamus; lateral septum; optogenetics; pathways

\section{Introduction}

Melanin-concentrating hormone $(\mathrm{MCH})$, one product of the pro-MCH gene, is synthesized exclusively in the lateral hypothalamus (Nahon et al., 1989) and has well documented effects on energy balance (Shimada et al., 1998). MCH neurons are also involved in rapid eye movement sleep regulation (Hassani et al., 2009), cognition (Monzon et al., 1999), mood (Roy et al., 2006, 2007), reward (Georgescu et al., 2005), and olfaction (Adams et al., 2011).

Anterograde and retrograde tracing demonstrated widespread $\mathrm{MCH}$ projections throughout the brain (Bittencourt, 2011). MCH receptor 1 (MCHR1)-expressing neurons are also widely distributed (Chee et al., 2013), but because of presynaptic MCHR1 actions (Zheng et al., 2005; Rao et al., 2008) and low peptide content at axon terminals, it is difficult to identify active targets of $\mathrm{MCH}$ neurons. Hence, $\mathrm{MCH}$ circuitry is not well understood, and synaptic mechanisms controlling downstream neuronal activity remain elusive.

$\mathrm{MCH}$ neurons coexpress additional neurotransmitters, including pro-MCH neuropeptides NEI and NGE (Nahon et al., 1989; Parkes and Vale, 1992), cocaine and amphetamine-related transcript (Broberger, 1999), as well as classical neurotransmit-

Received Oct. 9, 2014; revised Dec. 11, 2014; accepted Jan. 7, 2015.

Author contributions: M.J.S.C. and E.M.-F. designed research; M.J.S.C. performed research; M.J.S.C. and E.A. analyzed data; M.J.S.C., E.A., and E.M.-F. wrote the paper.

This work was supported by discretionary funding to E.M.-F. We thank Dr. Bradford Lowell (Beth Israel Deaconess Medical Center, Boston, MA) for the Rpl10-GFP reporter, SIC32a1-ires-cre, and SIc17a6-ires-cre mouse lines. We thank Dr. Loris Ferrari for intellectual discussions and Stephen Flaherty for technical contributions.

The authors declare no competing financial interests.

Correspondence should be addressed to Eleftheria Maratos-Flier, 3 Blackfan Circle, CLS 737, Boston, MA 02115. E-mail: emaratos@bidmc.harvard.edu.

DOI:10.1523/JNEUROSCI.4187-14.2015

Copyright $\odot 2015$ the authors $\quad 0270-6474 / 15 / 353644-08 \$ 15.00 / 0$ ters. They express GABA-synthesizing enzymes GAD65 and GAD67 (Elias et al., 2001; Harthoorn et al., 2005), and some $\mathrm{MCH}$ varicosities colocalize the vesicular GABA transporter vGAT (Del Cid-Pellitero and Jones, 2012), suggesting that MCH neurons release GABA (Jego et al., 2013). Interestingly, some MCH neurons also contain glutamate (Abrahamson et al., 2001) and express the excitatory amino-acid transporter EAAT3 (Collin et al., 2003) and vesicular glutamate transporters vGLUT1 and vGLUT2 (Harthoorn et al., 2005; Del Cid-Pellitero and Jones, 2012). However, there is no direct evidence that they release glutamate.

To better analyze $\mathrm{MCH}$ circuitry, we first expressed synaptophysin-mCherry in $\mathrm{MCH}$ cells to map their axon terminal distribution. Next, we tested their functional connectivity at downstream targets using an optogenetic approach by exclusively expressing and photostimulating channelrhodopsin-2 (ChR2) in $\mathrm{MCH}$ neurons and axons. We focused on the lateral septal nucleus (LS), which contained the densest $\mathrm{MCH}$ nerve terminals, and tested LS responses while photostimulating $\mathrm{MCH}$ projections.

\section{Materials and Methods}

Animals

Mice were treated in accordance with National Institutes of Health Guide for the Care and Use of Laboratory Animals guidelines. All protocols were approved by Beth Israel Deaconess Medical Center Institutional Animal Care and Use Committee.

Pmch-cre mice use the Pmch gene promoter to restrict crerecombinase expression in $\mathrm{MCH}$ neurons (Kong et al., 2010). Specificity of cre-expressing $\mathrm{MCH}$ neurons was assessed in Pmch-cre;tdTomato mice ( $n=2)$ obtained by crossing Pmch-cre (stock \#014099; The Jackson Laboratory) and tdTomato reporter (Gt(ROSA)26Sor-loxSTOPlox-tdTomato; stock \#007905; The Jackson Laboratory) mice (Madisen et al., 2012). 

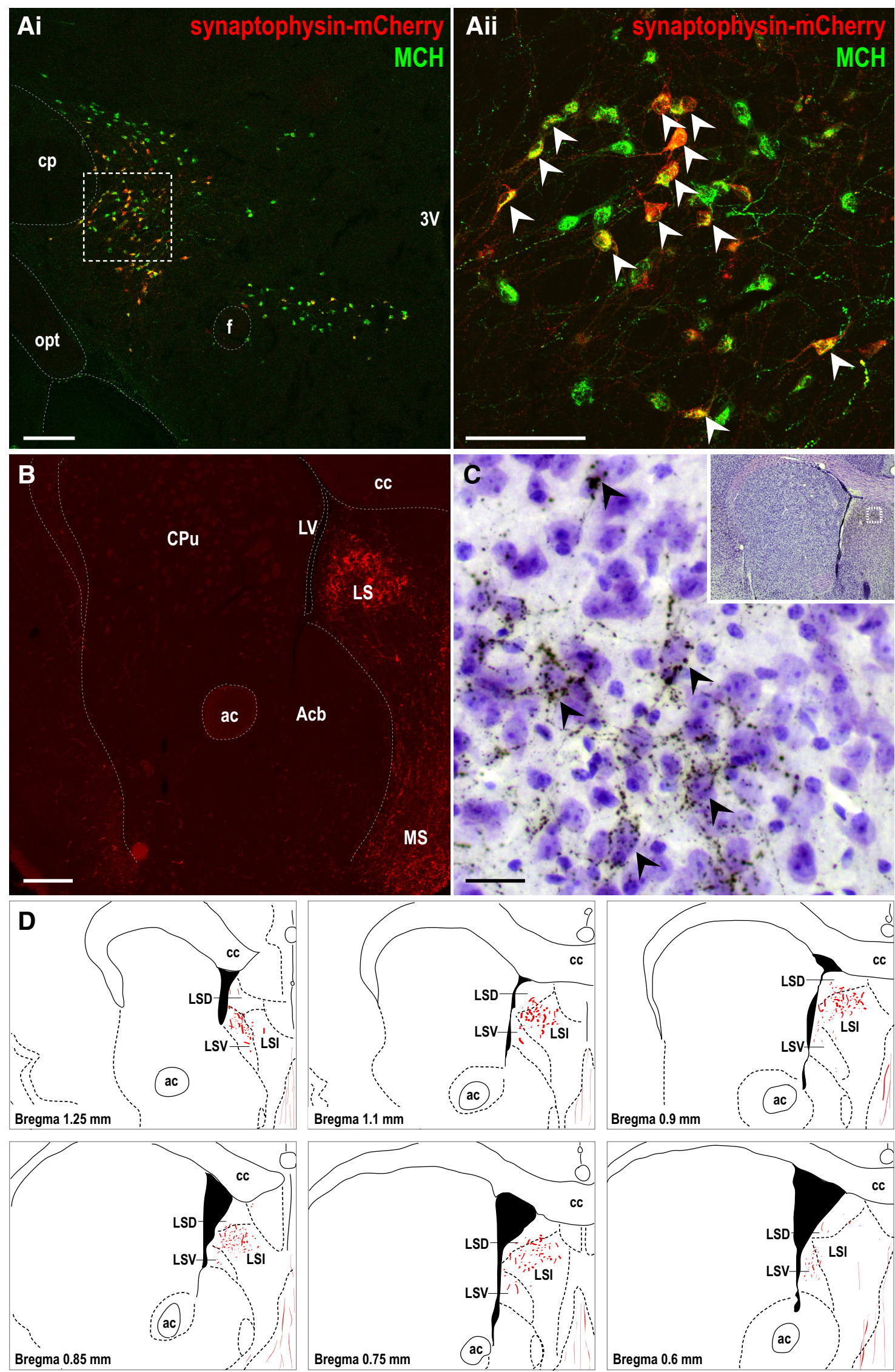

Figure 1. The LS receives dense MCH axon terminals. A, Merged low-magnification (i) and high-magnification (ii, outlined from $i$ ) confocal photomicrographs showing native synaptophysin$\mathrm{mCherry} \mathrm{fluorescence} \mathrm{(red)} \mathrm{and} \mathrm{MCH} \mathrm{immunoreactivity} \mathrm{(green)} \mathrm{in} \mathrm{the} \mathrm{lateral} \mathrm{hypothalamus} \mathrm{of} \mathrm{Pmch-cre} \mathrm{mice} \mathrm{injected} \mathrm{with} \mathrm{AAV8} \mathrm{-DI0-Ef1} \alpha$-synaptophysin-mCherry. White arrowheads mark some representative double-labeled neurons (yellow). B, Epifluorescence photomicrograph of the LS showing native synaptophysin-mCherry-labeled fluorescent (Figure legend continues.) 
Neurons expressing vGAT (Slc32a1) and vGLUT2 (Slc17a6) were identified in Slc32a1-cre;Rpl10-GFP $(n=2)$ and Slc17a6-cre;Rpl10-GFP mice ( $n=2$ ), obtained by breeding Slc32a1-ires-cre (stock \#016962; The Jackson Laboratory) and Slc17a6-ires-cre (stock \#016963; The Jackson Laboratory) mice (Vong et al., 2011), respectively, to cre-dependent GFP reporter mice (R26-loxSTOPlox-L10-GFP) in which cre activates Rpl10 and yields eGFP-fused L10-ribosomal subunit expression (Krashes et al., 2014).

\section{Stereotaxic viral injections}

Pmch-cre mice of either gender (8-12 weeks) were injected unilaterally with $480 \mathrm{nl}$ of cre-dependent adeno-associated viral (AAV) vectors (University of North Carolina Gene Therapy Center) encoding synaptophysin-mCherry (AAV8-EF1 $\alpha$-DIO-synaptophysin-mCherry; titer, $2.23 \times$ $10^{13}$ genomic copies $/ \mathrm{ml} ; n=3$ mice) or ChR2-mCherry (AAV8-EF1 $\alpha$ DIO-hChR2(H134R)-mCherry; titer, $3.82 \times 10^{12}$ genomic copies $/ \mathrm{ml}$; $n=18$ mice) to the medial (in mm: anteroposterior, -1.30 ; mediolateral, -0.50 ; dorsoventral, $-4.50,-5.00$ ) and lateral (in mm: anteroposterior, -1.80 ; mediolateral, -1.20 ; dorsoventral $-4.50,-5.00) \mathrm{MCH}$ field (Franklin and Paxinos, 1997). In vitro optogenetic experiments were performed 4-8 weeks after AAV injections.

\section{Immunohistochemistry}

Slc32a1-cre;Rpl10-GFP and Slc17a6-cre;Rpl10-GFP mice. GABAergic or glutamatergic MCH neurons were stained for GFP and MCH immunoreactivity in Formalin-fixed sections $(30 \mu \mathrm{m})$ and then incubated with anti-rabbit MCH (1:5000; Chee et al., 2013) and anti-chicken GFP antibody (1:3000; Invitrogen) overnight, followed by goat anti-rabbit Alexa Fluor 594 (1:300; Invitrogen) and goat anti-chicken Alexa Fluor 488 (1:300; Invitrogen) for $2 \mathrm{~h}$.

Pmch-cre mice. Synaptophysin-mCherry- or ChR2-mCherryexpressing sections were incubated with anti-rabbit MCH (1:5000; $24 \mathrm{~h})$, followed by goat anti-rabbit Alexa Fluor 488 (1:300; 2 h; Invitrogen).

Distribution of synaptophysin-mCherry-labeled end terminals were mapped in brain sections incubated with anti-rabbit Discosoma red (DsRed) antibody (1:3000; $24 \mathrm{~h}$; Clontech), followed by biotinconjugated goat anti-rabbit (1:1000; 1 h; Jackson ImmunoResearch) and avidin-biotin complex (1:500; Vectastain ABC kit; $1 \mathrm{~h}$; Vector Laboratories) before reacting with $3,3^{\prime}$-diaminobenzidine (DAB peroxidase substrate kit; $1.5 \mathrm{~min}$; Vector Laboratories). Sections were treated with xylene (16 h), Nissl stained with $0.1 \%$ cresyl violet $(1 \mathrm{~min})$, and then coverslipped with Permaslip (Alban Scientific). All incubations occurred at $22^{\circ} \mathrm{C}$.

Confocal image stacks were acquired with a Zeiss Imager confocal microscope using PASCAL software (Carl Zeiss). One-channel epifluorescence and bright-field photomicrographs were acquired with an Imager.A1 light microscope using AxioVision software (Carl Zeiss).

\section{Electrophysiology}

Slice preparation. Coronal brain slices $(250 \mu \mathrm{m})$ were prepared in icecold, carbogenated $\left(95 \% \mathrm{O}_{2}, 5 \% \mathrm{CO}_{2}\right)$ sucrose-based ACSF [in mM: 250 sucrose, $2.5 \mathrm{KCl}, 1.24 \mathrm{NaH}_{2} \mathrm{PO}_{4}, 10 \mathrm{MgCl}_{2}, 10$ glucose, $26 \mathrm{NaHCO}_{3}$, and $\left.0.5 \mathrm{CaCl}_{2}(305 \mathrm{mOsm} / \mathrm{L})\right]$ and then incubated $\left(15 \mathrm{~min} ; 37^{\circ} \mathrm{C}\right)$ in carbogenated ACSF [in mu: $124 \mathrm{NaCl}, 2.5 \mathrm{KCl}, 1.24 \mathrm{NaH}_{2} \mathrm{PO}_{4}, 1.3 \mathrm{MgCl}_{2}, 10$ glucose, $26 \mathrm{NaHCO}_{3}$, and $\left.2.5 \mathrm{CaCl}_{2}(300 \mathrm{mOsm} / \mathrm{L})\right]$ to recover $\left(>1 \mathrm{~h} ; 22^{\circ} \mathrm{C}\right)$.

Patch-clamp recording. While slices equilibrated $\left(31^{\circ} \mathrm{C}\right)$, ChR2mCherry expression was assessed using epifluorescence illumination (Examiner.A1; Carl Zeiss). Individual neurons were visualized for wholecell patch using infrared differential interference contrast (IR-DIC). Voltage-clamp recordings were obtained with a pipette containing the

$\leftarrow$

(Figure legend continued.) fibers. C, High-magnification bright-field photomicrograph (outlined in inset) showing punctate DsRed-IRboutons (dark brown) surrounding Niss--stained LS cells (purple). Black arrowheads mark some representative $L S$ soma outlined by DsRed-labeled terminals. D, Line drawings mapping DsRed immunoreactivity distribution within the $L S .3 V$, Third ventricle; ac, anterior commissure; $\mathrm{Acb}$, accumbens nucleus; $c c$, corpus callosum; $\mathrm{C}$, cerebral peduncle; $\mathrm{CPu}$, caudate putamen; f, fornix; LSD, lateral septal nucleus, dorsal part; LSI, lateral septal nucleus, intermediate part; LSV, lateral septal nucleus, ventral part; LV, lateral ventricle; MS, medial septal nucleus; opt, optictract. Scale bars: Ai, B, $200 \mu \mathrm{m} ; A i i, 100 \mu \mathrm{m} ; C, 20 \mu \mathrm{m}$. following (in mM): 125 Cs-methanesulfonate, $11 \mathrm{KCl}, 10 \mathrm{HEPES}, 0.1$ $\mathrm{CaCl}_{2}$, 1 EGTA, $5 \mathrm{MgATP}$, and $0.3 \mathrm{NaGTP}$ (290 mOsm/L), pH 7.24. Current-clamp recordings were obtained with a pipette containing the following (in mM): $137 \mathrm{~K}$-gluconate, $5 \mathrm{KCl}, 1 \mathrm{MgCl}_{2}, 4 \mathrm{MgATP}, 10$ creatine, $0.4 \mathrm{NaGTP}, 10$ HEPES, and 0.1 EGTA (290 mOsm/L), pH 7.24. Recordings were acquired with a MultiClamp 700B amplifier (Molecular Devices) digitizing via a Digidata 1440A (Molecular Devices) interface using pClamp 10 software (Molecular Devices). Cells whose input resistances deviated $>10 \%$ over time were excluded from analysis.

Photostimulation protocol. Photostimulation was provided by fullfield, $5 \mathrm{~ms}$ light pulses ( $470 \mathrm{~nm}$; power density, $10 \mathrm{~mW} / \mathrm{mm}^{2}$ ) using a 5 W Luxeon blue light-emitting diode (Thorlabs). Optogenetically evoked currents (oIPSC or oEPSC) were elicited with three light pulses delivered $500 \mathrm{~ms}$ apart, repeated for 20 trials every $4 \mathrm{~s}$, and then averaged for quantification. Delay latency was measured as time between onset of light pulse and current event. Effects on firing were elicited by three trials of 10 $\mathrm{Hz}$ trains lasting $5 \mathrm{~s}$. Experiments using tetrodotoxin (TTX) were performed in 1 mm 4-AP (Petreanu et al., 2009).

\section{Chemicals}

All drugs were prepared immediately before use and administered by bath perfusion. All chemicals were from Sigma-Aldrich, except TTXcitrate (Alomone Labs).

\section{Data and statistical analysis}

Unilateral cell counts were obtained from flattened confocal images. Recording data were analyzed using Clampfit 10 (Molecular Devices). Synaptic events were analyzed using MiniAnalysis (Synaptosoft). Graphs and sample traces were generated with Prism 5 (GraphPad Software) and Axum 5 (MathSoft). Data are represented as mean \pm SEM. The number of cells per group $(n)$ is shown in parentheses in the figures. Means were compared using the paired $t$ test; $t$ values and degrees of freedom $\left(t_{(\mathrm{df})}\right)$ are provided at significant differences of $p<0.05$.

\section{Results}

\section{The LS is a target of MCH nerve terminals}

Using Pmch-cre; tdTomato mice, we observed tdTomato colocalization in $98 \pm 2 \%$ of $\mathrm{MCH}$-immunoreactive (IR) cells. We then identified $\mathrm{MCH}$ nerve terminals by injecting AAV-DIO-synaptophysin-mCherry into the lateral hypothalamus of $\mathrm{MCH}$-cre mice. Synaptophysin-mCherry was expressed in $35 \pm 14 \%$ of MCH-IR neurons (Fig. 1A). No mCherry-labeled cells were found outside the $\mathrm{MCH}$ region.

mCherry-labeled $\mathrm{MCH}$ projections were observed throughout the brain, including the lateral and posterior hypothalamus, ventral tegmental area, colliculus, periaqueductal gray, and parabrachial nucleus. Areas with the highest MCHR1 mRNA expression (Chee et al., 2013), particularly the striatum, arcuate, and paraventricular hypothalamic nucleus, contained few mCherrylabeled fibers. In contrast, dense clusters of mCherry-labeled nerve terminals accumulated in the LS (Fig. 1B). Punctate DsRed (mCherry) immunoreactivity in Nissl-stained sections revealed nerve terminals that closely appose LS neurons (Fig. $1 C$ ) and map predominantly to the intermediate part of the LS (Fig. 1D).

\section{$\mathrm{MCH}$ neurons release glutamate in the LS}

We examined long-range, functional connectivity between $\mathrm{MCH}$ and LS neurons by GABAergic and/or glutamatergic transmission. Using Slc32a1-cre;Rpl10-GFP and Slc17a6-cre;Rpl10GFP mice, we first identified vGAT- or vGLUT2-expressing $\mathrm{MCH}$ neurons. Almost all MCH-IR cells colocalized with vGLUT2 labeling, but none were vGAT positive (Fig. 2).

We then assessed GABA and glutamate release in LS using optogenetics. Injection of AAV-DIO-ChR2-mCherry in Pmch-cre mice resulted in ChR2-mCherry expression at $32 \pm 9 \%$ of MCH-IR neu- 

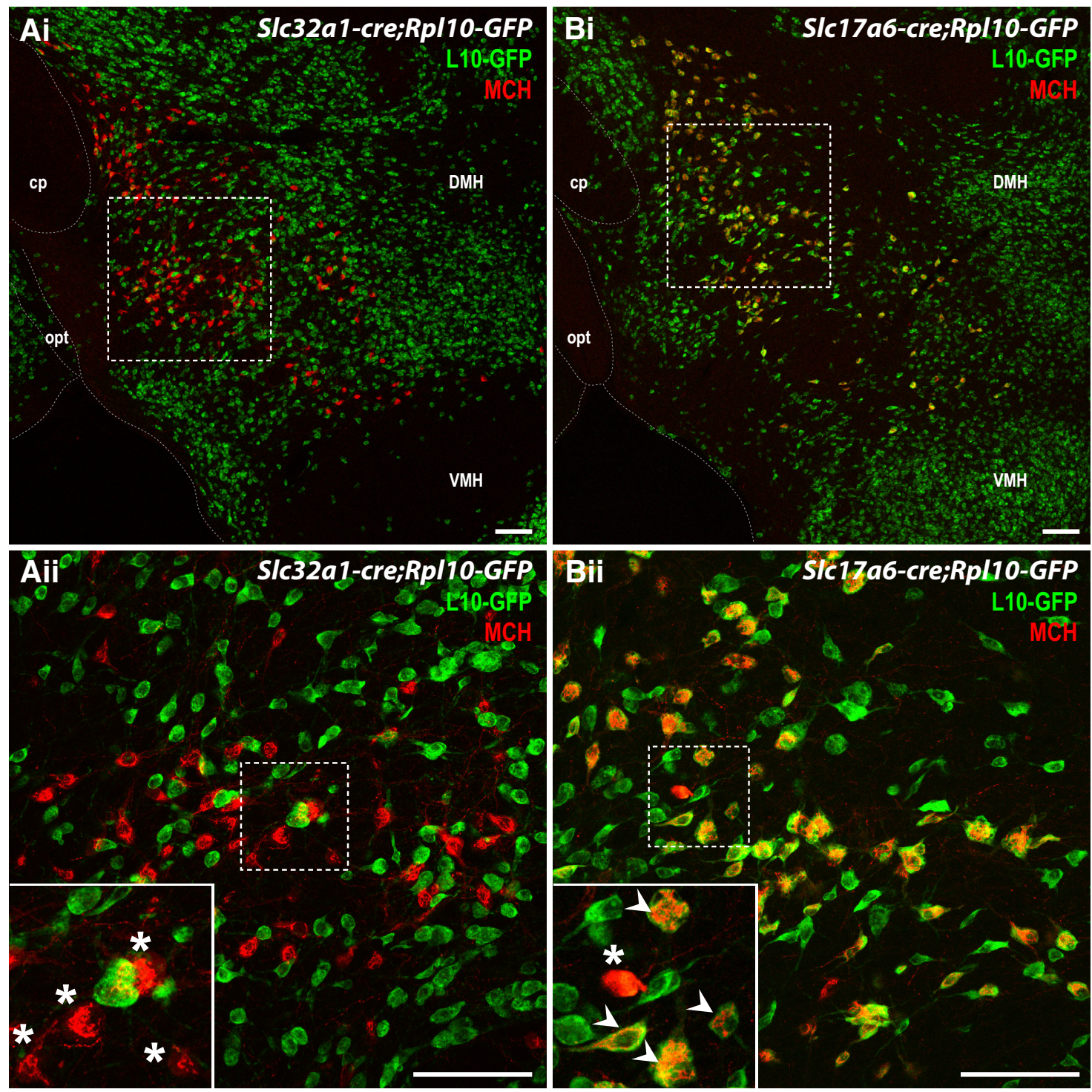

\begin{tabular}{|c|c|c|c|}
\hline \multirow[b]{2}{*}{ Mouse } & \multicolumn{2}{|c|}{ Total cell count ${ }^{1}$} & \multirow{2}{*}{$\begin{array}{c}\text { Percent }(\%)^{3} \\
\frac{\text { Colocalized }}{\text { MCH-IR }}\end{array}$} \\
\hline & MCH-IR & $\begin{array}{c}\text { MCH-IR + GFP } \\
\left(\text { colocalized }^{2}\right)\end{array}$ & \\
\hline Slc32al-cre;Rpl10-GFP & $529 \pm 46$ & $1 \pm 1$ & $0.3 \pm 0.1$ \\
\hline Slc17a6-cre;Rpl10-GFP & $490 \pm 70$ & $463 \pm 79$ & $94.0 \pm 2.6$ \\
\hline
\end{tabular}

${ }_{1}$ Quantitation of MCH-IR neurons that are GABAergic or glutamatergic by GFP coexpression in Slc32al-cre;rpl10-GFP or Slc17a6-cre;Rpl10-GFP mice, respectively. Cells (mean $\pm \mathrm{SEM}, n=2$ mice) are counted unilaterally.

2 Labeling of vGAT or vGLUT2 neurons was determined by native GFP fluorescence (green). MCH-IR cells are labeled with Alexa Fluor 594 (red). Colocalized neurons appear yellow.

3 Ratio describing the percentage of MCH-IR neurons that are vGAT or vGLUT2 positive.

Figure 2. MCH neurons express vGLUT2 but not vGAT. $A, B$, Merged low-magnification (i) and high-magnification (ii, outlined in $i$ ) confocal photomicrographs showing MCH immunoreactivity (red) in GFP-positive (green) vGAT $(\boldsymbol{A})$ and vGLUT2 (B) neurons. Insets (outlined in Aii and Bii) showing the colocalization of MCH immunoreactivity with vGLUT2 but not vGAT expression. White arrowheads indicate double-labeled neurons (yellow). Asterisks mark non-colocalized MCH neurons. Scale bars:i, $200 \mu \mathrm{m} ; \mathrm{ii}, 100 \mu \mathrm{m}$. C, Unilateral cell count of MCH-IR neurons expressing vGAT or vGLUT2. cp, Cerebral peduncle; DMH, dorsomedial hypothalamic nucleus; opt, optic tract; VMH, ventromedial hypothalamic nucleus.

rons. Recording and photostimulating mCherry-labeled neurons (Fig. $3 A, B$ ) with single blue light flashes evoked temporally correlated action potentials. Light pulse trains up to $20 \mathrm{~Hz}$ entrained $\mathrm{MCH}$ cell firing with high spike fidelity $(99.8 \pm 0.2 \%, n=12)$, which fell substantially at higher light frequencies $(50 \mathrm{~Hz}, 35.4 \pm$
$9.0 \%, n=12 ; 100 \mathrm{~Hz}, 3.6 \pm 1.0 \%, n=12$; Fig. $3 C$ ). Photostimulation between 20 and $50 \mathrm{~Hz}$ resulted in firing rates of $\sim 20 \mathrm{~Hz}$, the maximal firing observed by MCH neurons in vivo (Hassani et al., 2009); stimulations above $50 \mathrm{~Hz}$ produced a depolarizing block (Fig. 3C). 

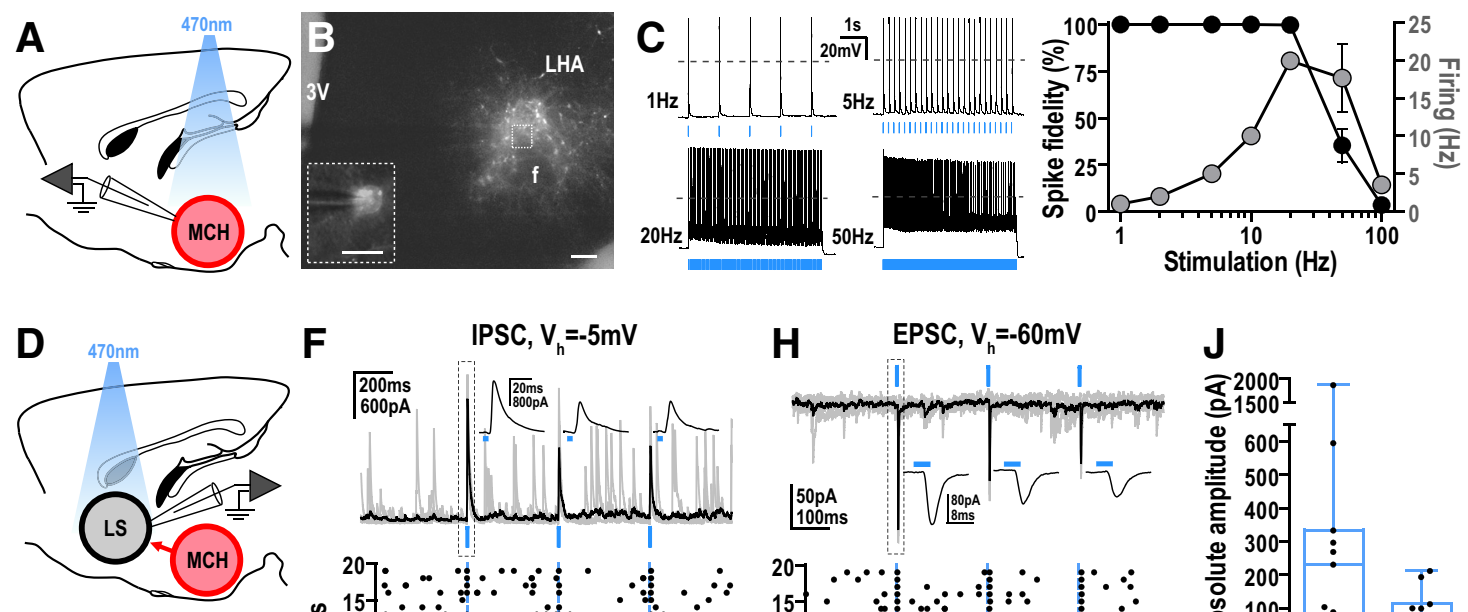

$\mathbf{F}$
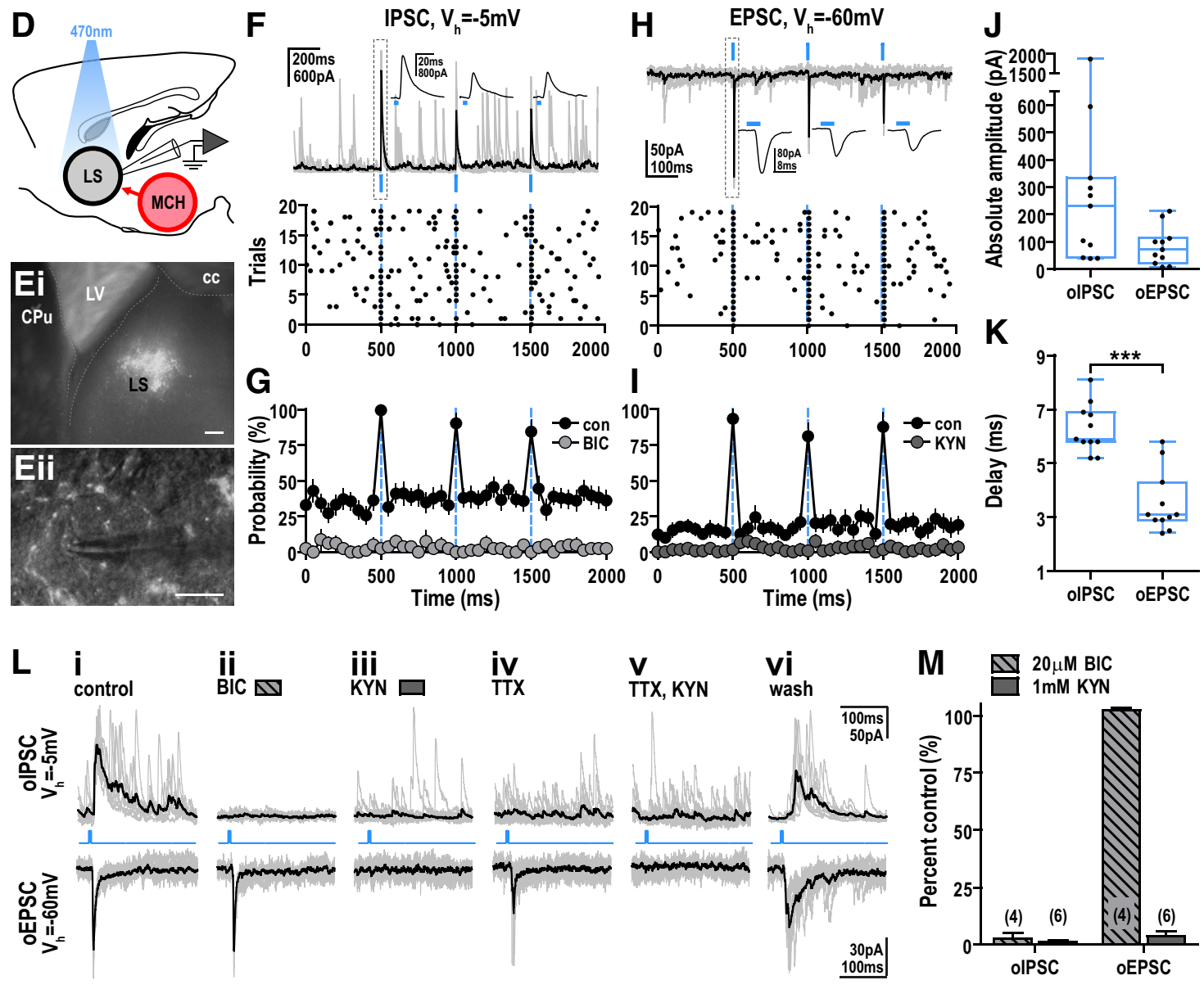

Figure 3. Photostimulation of ChR2-expressing $M C H$ terminals evoked glutamate release in the $L S$. $A$, Experimental design schematic showing patch-clamp recording while photostimulating ChR2-expressing MCH neurons. B, Merged epifluorescence and IR-DIC photomicrographs of a coronal Pmch-cre brain slice injected with AAV8-EF1 $\alpha-D I 0-h C h R 2$ (H134R)-mCherry showing whole-cell recording from a mCherry-labeled MCH neuron (inset, outlined region). Scale bars: $200 \mu \mathrm{m}$; inset, $50 \mu \mathrm{m}$. C, Sample traces of action potential firing from a ChR2-expressing MCH neuron evoked by 5 s light trains ( $5 \mathrm{~ms}$ pulses) at 1,5,20, and $100 \mathrm{~Hz}$ light frequency (dashed line, $0 \mathrm{mV}$; left). Percentage change in spike fidelity (black, left axis) and $\mathrm{MCH}$ neuronal firing (gray, right axis) showing effective entrainment up to $20 \mathrm{~Hz}$ photostimulation $(n=12)$. $\boldsymbol{D}$, Experimental design schematic showing whole-cell recordings from $L S$ neurons while photostimulating ChR2-expressing MCH projections. $\boldsymbol{E}$, Merged low-magnification (i) and high-magnification (ii) epifluorescence and IR-DIC photomicrographs of a coronal brain slice showing ChR2-expressing MCH axon terminals in the $L S(\boldsymbol{i})$ and mCherry-fluorescent puncta outlining LS cells (ii). Scale bars: i, $200 \mu \mathrm{m} ; \boldsymbol{i i}, 100 \mu \mathrm{m}$. $\boldsymbol{F}-\boldsymbol{I}$, Overlay of individual (gray) and averaged (black) olPSCS $\left(V_{\mathrm{h}}\right.$ of $\left.-5 \mathrm{mV} ; \boldsymbol{F}\right)$ and oEPSCS $\left(V_{\mathrm{h}}\right.$ of $-60 \mathrm{mV} ; \boldsymbol{H}$ ) after photostimulation ( 35 -ms light pulses in $1 \mathrm{~s}$, repeated every $5 \mathrm{~s}$ for 20 trials). Averaged responses $(\boldsymbol{F}, \boldsymbol{H})$ magnified in insets (top) and raster plots (bottom; $50 \mathrm{~ms}$ bins) showing event synchronization during photostimulation. Probability plots ( $50 \mathrm{~ms}$ bins) showing that photostimulation increased IPSC and EPSC probability in control (con; $n=14$ ), which is abolished by 20 $\mu \mathrm{M} \mathrm{BIC}(n=4 ; \boldsymbol{G})$ and $1 \mathrm{~mm}$ KYN $(n=6 ; \boldsymbol{I})$, respectively. $\boldsymbol{J}, \boldsymbol{K}$, Range (line, median; box, 25th to 75 th percentiles; whisker, minimum to maximum) of absolute amplitudes ( $(\boldsymbol{)})$ and delay latency ( $\boldsymbol{K})$ of oIPSCs and oEPSCs averaged from 20 trials. ${ }^{* * *} p<0.001$. L, Overlay of individual (gray) and averaged (black) olPSCS (top) and oEPSCs (bottom) in control (i), BIC (iii), KYN (iii), $500 \mathrm{~nm} \mathrm{TTX} \mathrm{(iv),}$ TTX and KYN (v), and washout (vi). M, Effect of KYN and BIC on oIPSC and oEPSC amplitude. 3V, Third ventricle; cc, corpus callosum; con, control; CPu, caudate putamen; f, fornix; LHA, lateral hypothalamic area; LV, lateral ventricle.

To evaluate neurotransmitter release, we recorded LS cells and photostimulated the surrounding ChR2-expressing nerve terminals (Fig. 3D,E). A dual response was evoked from the same cell using cesium-filled electrodes. At $V_{\mathrm{h}}$ of $-5 \mathrm{mV}$, single light pulses evoked temporally correlated oIPSCs (Fig. $3 F$ ). This increased baseline IPSC probability from $36.4 \pm 7.0$ to $96.5 \pm 5.7 \%(n=$ $14, t_{(13)}=8.14, p<0.0001$ ), an effect blocked by $20 \mu \mathrm{M}$ bicuculline (BIC), a $\mathrm{GABA}_{\mathrm{A}}$ receptor antagonist (Fig. $3 G$ ). At $V_{\mathrm{h}}$ of -60 $\mathrm{mV}$, photostimulation evoked oEPSCs (Fig. $3 \mathrm{H}$ ) and increased
EPSC probability from $13.7 \pm 4.7$ to $93.2 \pm 6.7 \%\left(n=14, t_{(13)}=\right.$ $10.31, p<0.0001$ ). This was blocked by $1 \mathrm{~mm}$ kynurenic acid $(\mathrm{KYN})$, a broad-spectrum glutamate receptor antagonist (Fig. $3 I$ ). This collectively suggested that activating $\mathrm{MCH}$ efferents evoked both GABA and glutamate release.

The amplitude of GABA-mediated oIPSCs $(354.9 \pm 159.5 \mathrm{pA}$, $n=11)$ tended to be larger than glutamate-mediated oEPSCs $(-83.9 \pm 20.9 \mathrm{pA}, n=11$; Fig. $3 J)$. The oEPSC delay latency was $3.5 \pm 0.3 \mathrm{~ms}(n=11)$, consistent with a monosynaptic connec- 
Ai

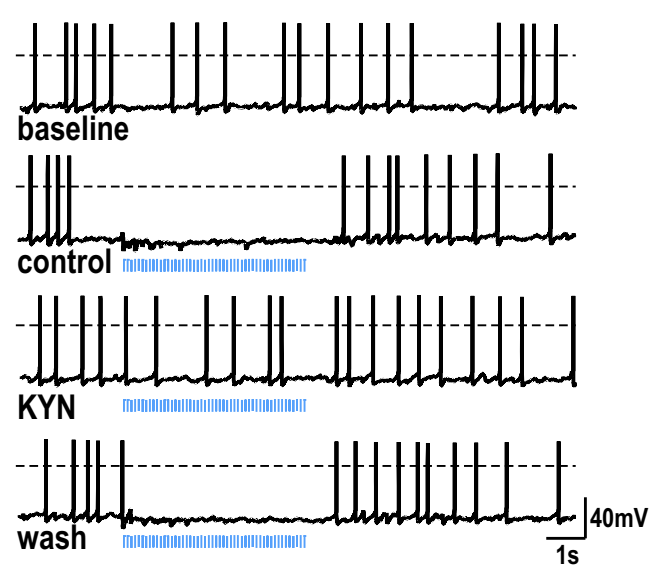

Bi
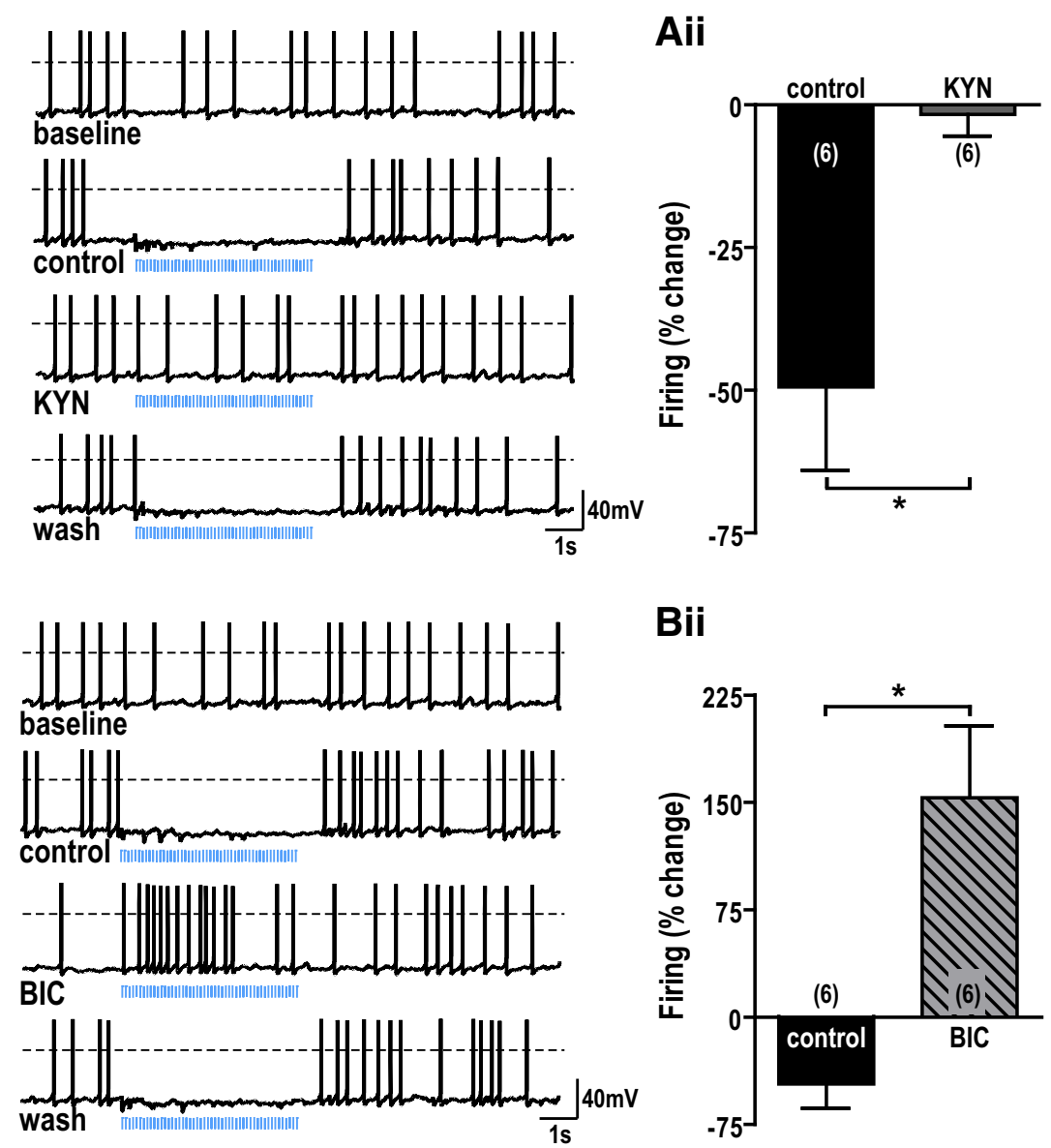

C

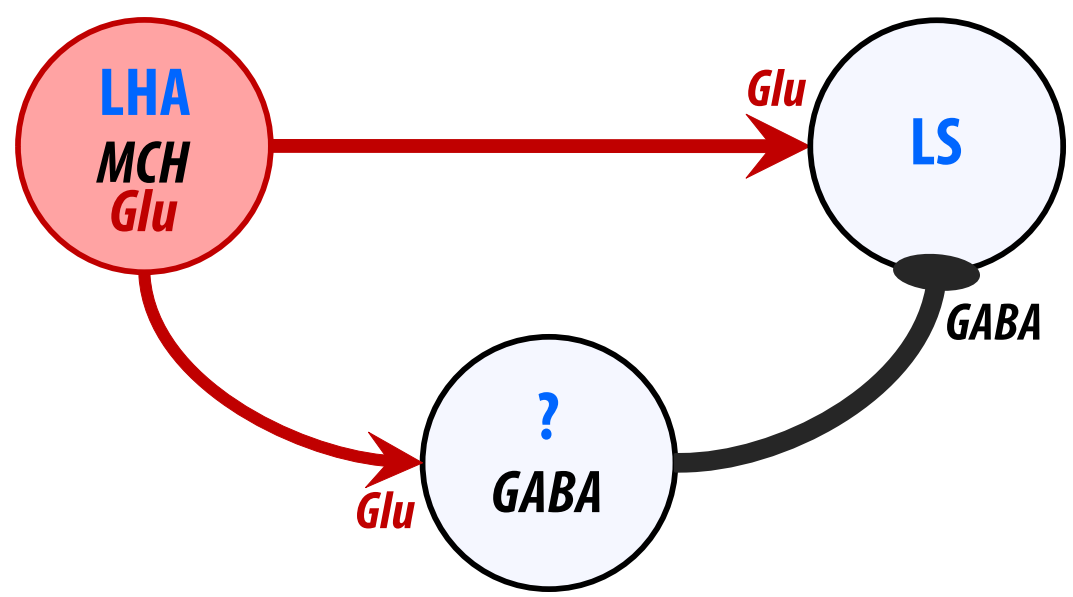

Figure 4. Photostimulation of MCH terminals inhibited $L S$ cells by glutamate-mediated GABA release. $A, B$, Sample trace $(\boldsymbol{i})$ and mean percentage change (ii) in spontaneous $L S$ firing frequency in response to photostimulation ( $5 \mathrm{~ms}$ light pulses, $10 \mathrm{~Hz}$ train for 5 s) before (control), during $1 \mathrm{~mm} \mathrm{KYN}(\boldsymbol{A})$ or $20 \mu \mathrm{M} \mathrm{BIC}(\boldsymbol{B})$, and after washout (wash). ${ }^{*} p<0.05$. C, Model of monosynaptic and disynaptic pathways between $M C H$ and $L S$ neurons. MCH neurons in the lateral hypothalamic area (LHA) directly release glutamate (Glu) onto LS neurons and GABAergic interneurons or afferents. Glutamate release at GABAergic intermediates elicits robust feedforward inhibition of LS neuronal activity.

tion. In contrast, oIPSC delay was nearly twofold longer (6.3 \pm $0.3 \mathrm{~ms}, n=11, t_{(10)}=11.99, p<0.0001$; Fig. $\left.3 \mathrm{~K}\right)$, suggesting a polysynaptic connection. We next evaluated the effect of BIC and KYN pretreatment on these optogenetically evoked currents (Fig. $3 \mathrm{Li})$. Expectedly, BIC blocked oIPSCs $(-97.4 \pm 2.6 \%, n=4$; Fig. 3 Lii, M ) and KYN blocked oEPSCs ( $-96.1 \pm 2.1 \%, n=6$; Fig. 3 Liii, $M)$. However, KYN also abolished oIPSCs (-98.8 $\pm 0.7 \%$, $n=6$; Fig. 3 Liii, M). This indicated that glutamatergic oEPSCs were independent of GABA transmission but that GABAergic oIPSCs require upstream glutamate release. Furthermore, eliminating activity-dependent polysynaptic events with $500 \mathrm{~nm}$ TTX abolished GABAergic oIPSCs but not glutamatergic oEPSCs (Fig. 3Liv, Lv). Aggregate results indicated that $\mathrm{MCH}$ neurons directly release glutamate onto LS neurons, while producing feedforward inhibition of LS neurons through activation of either GABAergic afferents or interneurons.

\section{Photostimulation of MCH axons inhibited LS firing}

We next determined whether inputs from $\mathrm{MCH}$ neurons control LS action potential firing. Photostimulation of $\mathrm{MCH}$ axon terminals $(10 \mathrm{~Hz}, 5 \mathrm{~s}$ train) transiently suppressed LS firing ( $2.7 \pm 0.8$ to $1.6 \pm$ $\left.0.7 \mathrm{~Hz}, n=11, t_{(10)}=4.80, p<0.001\right)$, which returned to baseline during lights off $(2.6 \pm 0.8 \mathrm{~Hz}, n=11)$. KYN abolished this light-mediated inhibition of LS neurons (control, $-49.5 \pm 14.6 \%, n=6$; $\mathrm{KYN},-1.7 \pm 3.8 \%, n=6 ; t_{(5)}=3.36$, $p<0.05$; Fig. 4A), consistent with a glutamate-mediated feedforward inhibition of this population. Photostimulation of $\mathrm{MCH}$ end terminals in the presence of BIC increased LS firing by $153.3 \pm 50.2 \%$ $(n=6$; control, $-46.7 \pm 17.1 \%, n=6$; $t_{(5)}=3.36, p<0.05$; Fig. $\left.4 B\right)$, demonstrating that $\mathrm{MCH}$ neurons directly release glutamate to stimulate LS cells.

\section{Discussion}

This is the first demonstration of a functional pathway between $\mathrm{MCH}$ and LS neurons. $\mathrm{MCH}$ regulates fundamental physiological functions, including energy homeostasis and sleep. It is also involved in complex behaviors, such as reproduction, olfaction, aggression (Adams et al., 2011), and affective disorders (Roy et al., 2007), but no neuroanatomical substrate is yet identified as a conduit for these complex behaviors. The LS is an intriguing candidate. It is implicated in anxiety, depression, and aggression (Sheehan et al., 2004), consistent with its potential role mediating behavioral abnormalities in mice lacking MCH (Georgescu et al., 2005; Adams et al., 2011) or MCHR1 (Roy et al., 2006, 2007; Sherwood et al., 2012). It receives MCH projections (Jego et al., 2013), which we now demonstrate are active glutamatergic nerve terminals directly innervating LS neurons. Photostimulation of these axon terminals directly evoked glutamate release, followed by a delayed, secondary GABA release onto LS cells. Interestingly, the net response depressed LS firing. The source of GABA is still 
unknown but may derive from GABAergic afferents or interneurons innervating the LS (Fig. $4 C$ ).

Several reports suggest that $\mathrm{MCH}$ neurons are GABAergic because they can synthesize (Elias et al., 2001; Harthoorn et al., 2005; Jego et al., 2013) and release (Jego et al., 2013) GABA. Here we show that the majority of MCH neurons are vGLUT2 positive but none are vGAT positive. This suggests that they release glutamate and thus are not exclusively GABAergic. Similar to what is observed in neighboring histaminergic cells (Williams et al., 2014), MCH neurons can synthesize GABA but might lack the machinery to package it for synaptic release. Optogenetic stimulation of MCH inputs evoked GABA release in the LS, but GABA is not directly released by $\mathrm{MCH}$ terminals. Rather, it is secondary to the activation of glutamatergic $\mathrm{MCH}$ projections. It is possible that GABA is packaged by other vesicular monoamine transporters, such as vMAT2 (Tritsch et al., 2012), for release elsewhere in the brain (Jego et al., 2013) but not in the LS. Our findings, in conjunction with those of Jego et al. (2013), suggest the bilingual nature of $\mathrm{MCH}$ cells, akin to some neurons in the ventral tegmental area that cotransmit glutamate and GABA (Root et al., 2014).

$\mathrm{MCH}$ effects are associated typically with neuronal inhibition. $\mathrm{MCH}$ activates inhibitory $\mathrm{G}_{\mathrm{i}}$-coupled MCHR1 receptors (Pissios et al., 2003), reduces presynaptic activity (Gao, 2009), and suppresses neuronal firing (Wu et al., 2009; Sears et al., 2010). Stimulating $\mathrm{MCH}$ projections in the LS reduced action potential firing, but this does not reflect an inhibitory action of $\mathrm{MCH}$ but rather a glutamate-dependent GABA release. We thus propose a model in which the stimulation of MCH terminals leads to glutamate release and glutamate feeds forward to enable robust GABAergic inhibition of LS cells. Because LS activity is effectively regulated by this indirect pathway, our model highlights a role of $\mathrm{MCH}$ neurons to modulate the output of this GABAergic node (Fig. 4C). The source of this GABA output is not known but is likely derived locally within the LS. The LS contains GABAergic cells (Köhler and Chan-Palay, 1983; Onteniente et al., 1986), and LS cells are known to form collateral projections between LS subnuclei (Staiger and Nürnberger, 1991).

$\mathrm{MCH}$ nerve terminals in the LS comprise functional glutamatergic synapses but can also support $\mathrm{MCH}$ signaling. $\mathrm{MCH}-\mathrm{IR}$ fibers have been reported in the LS (Bittencourt et al., 1992; Bittencourt and Elias, 1998), and some LS cells express MCHR1 (Chee et al., 2013). However, our optogenetically evoked responses do not involve $\mathrm{MCH}$. The pattern of optogenetic-mediated neuropeptide release differs from fast classical neurotransmitters (Schöne et al., 2014), requiring higher photostimulation frequencies and detection over longer timeframes (Arrigoni and Saper, 2014). Here, the timing and kinetics of evoked responses are consistent with that of fast synaptic events. Furthermore, blocking glutamatergic and GABAergic transmission revealed no residual responses; thus, it is unlikely that $\mathrm{MCH}$ or other neuropeptides are involved in the observed effects.

It is interesting that the LS contains the densest $\mathrm{MCH}$ projections but is not the brain area with the highest density of MCHR1. MCHR1 is expressed throughout the brain, as shown by the distribution pattern of in situ hybridization (Saito et al., 1999) and recent mapping and characterization of MCHR1-expressing cells using the Mchr1-cre;tdTomato mouse (Chee et al., 2013). MCH effects have also been reported in several neuroanatomical areas. MCH action in the medial septum (Wu et al., 2009) is consistent with the high density of $\mathrm{MCH}$ nerve fibers. However, other reported sites of $\mathrm{MCH}$ action, including the accumbens (Sears et al., 2010) and arcuate nucleus (Davidowa et al., 2002), contained only few fibers (Croizier et al., 2010). Furthermore, the accum- bens and arcuate nucleus are known to express the highest level of MCHR1 (Chee et al., 2013). Mismatches between the distribution of projections, receptors, and action sites are not unique to $\mathrm{MCH}$ and have been described in peptidergic or nonpeptidergic transmitter systems (Herkenham, 1987; Tallent, 2008). In the $\mathrm{MCH}$ system, in which MCHR1 is plentiful but projections are sparse, $\mathrm{MCH}$ effects may be attributed to the fact that neuropeptides can act by volume transmission and diffuse through the tissue to their target sites (Tallent, 2008; van den Pol, 2012).

Our findings suggest that $\mathrm{MCH}$ neurons are not exclusively GABAergic, as purported, and can release glutamate. These results contribute fundamental mechanisms that define $\mathrm{MCH}$ circuitry. Furthermore, these studies define a functional synaptic mechanism at the LS that may underlie affective roles of $\mathrm{MCH}$ neuronal systems.

\section{References}

Abrahamson EE, Leak RK, Moore RY (2001) The suprachiasmatic nucleus projects to posterior hypothalamic arousal systems. Neuroreport 12:435440. CrossRef Medline

Adams AC, Domouzoglou EM, Chee MJ, Segal-Lieberman G, Pissios P, Maratos-Flier E (2011) Ablation of the hypothalamic neuropeptide melanin concentrating hormone is associated with behavioral abnormalities that reflect impaired olfactory integration. Behav Brain Res 224:195200. CrossRef Medline

Arrigoni E, Saper CB (2014) What optogenetic stimulation is telling us (and failing to tell us) about fast neurotransmitters and neuromodulators in brain circuits for wake-sleep regulation. Curr Opin Neurobiol 29C:165171. CrossRef Medline

Bittencourt JC (2011) Anatomical organization of the melanin-concentrating hormone peptide family in the mammalian brain. Gen Comp Endocrinol 172:185-197. CrossRef Medline

Bittencourt JC, Elias CF (1998) Melanin-concentrating hormone and neuropeptide EI projections from the lateral hypothalamic area and zona incerta to the medial septal nucleus and spinal cord: a study using multiple neuronal tracers. Brain Res 805:1-19. CrossRef Medline

Bittencourt JC, Presse F, Arias C, Peto C, Vaughan J, Nahon JL, Vale W, Sawchenko PE (1992) The melanin-concentrating hormone system of the rat brain: an immuno- and hybridization histochemical characterization. J Comp Neurol 319:218-245. CrossRef Medline

Broberger C (1999) Hypothalamic cocaine- and amphetamine-regulated transcript (CART) neurons: histochemical relationship to thyrotropinreleasing hormone, melanin-concentrating hormone, orexin/hypocretin and neuropeptide Y. Brain Res 848:101-113. CrossRef Medline

Chee MJ, Pissios P, Maratos-Flier E (2013) Neurochemical characterization of neurons expressing melanin-concentrating hormone receptor 1 in the mouse hypothalamus. J Comp Neurol 521:2208-2234. CrossRef Medline

Collin M, Bäckberg M, Ovesjö ML, Fisone G, Edwards RH, Fujiyama F, Meister B (2003) Plasma membrane and vesicular glutamate transporter mRNAs/proteins in hypothalamic neurons that regulate body weight. Eur J Neurosci 18:1265-1278. CrossRef Medline

Croizier S, Franchi-Bernard G, Colard C, Poncet F, La Roche A, Risold PY (2010) A comparative analysis shows morphofunctional differences between the rat and mouse melanin-concentrating hormone systems. PLoS One 5:e15471. CrossRef Medline

Davidowa H, Li Y, Plagemann A (2002) Hypothalamic ventromedial and arcuate neurons of normal and postnatally overnourished rats differ in their responses to melanin-concentrating hormone. Regul Pept 108:103111. CrossRef Medline

Del Cid-Pellitero E, Jones BE (2012) Immunohistochemical evidence for synaptic release of GABA from melanin-concentrating hormone containing varicosities in the locus coeruleus. Neuroscience 223:269-276. CrossRef Medline

Elias CF, Lee CE, Kelly JF, Ahima RS, Kuhar M, Saper CB, Elmquist JK (2001) Characterization of CART neurons in the rat and human hypothalamus. J Comp Neurol 432:1-19. CrossRef Medline

Franklin F, Paxinos G (1997) The mouse brain in stereotaxic coordinates. San Diego: Academic.

Gao XB (2009) Electrophysiological effects of MCH on neurons in the hypothalamus. Peptides 30:2025-2030. CrossRef Medline 
Georgescu D, Sears RM, Hommel JD, Barrot M, Bolaños CA, Marsh DJ, Bednarek MA, Bibb JA, Maratos-Flier E, Nestler EJ, DiLeone RJ (2005) The hypothalamic neuropeptide melanin-concentrating hormone acts in the nucleus accumbens to modulate feeding behavior and forced-swim performance. J Neurosci 25:2933-2940. CrossRef Medline

Harthoorn LF, Sañé A, Nethe M, Van Heerikhuize JJ (2005) Multitranscriptional profiling of melanin-concentrating hormone and orexincontaining neurons. Cell Mol Neurobiol 25:1209-1223. CrossRef Medline

Hassani OK, Lee MG, Jones BE (2009) Melanin-concentrating hormone neurons discharge in a reciprocal manner to orexin neurons across the sleep-wake cycle. Proc Natl Acad Sci U S A 106:2418-2422. CrossRef Medline

Herkenham M (1987) Mismatches between neurotransmitter and receptor localizations in brain: observations and implications. Neuroscience 23:1-38. CrossRef Medline

Jego S, Glasgow SD, Herrera CG, Ekstrand M, Reed SJ, Boyce R, Friedman J, Burdakov D, Adamantidis AR (2013) Optogenetic identification of a rapid eye movement sleep modulatory circuit in the hypothalamus. Nat Neurosci 16:1637-1643. CrossRef Medline

Köhler C, Chan-Palay V (1983) Distribution of gamma aminobutyric acid containing neurons and terminals in the septal area. An immunohistochemical study using antibodies to glutamic acid decarboxylase in the rat brain. Anat Embryol (Berl) 167:53-65. CrossRef

Kong D, Vong L, Parton LE, Ye C, Tong Q, Hu X, Choi B, Brüning JC, Lowell BB (2010) Glucose stimulation of hypothalamic MCH neurons involves $\mathrm{K}(\mathrm{ATP})$ channels, is modulated by UCP2, and regulates peripheral glucose homeostasis. Cell Metab 12:545-552. CrossRef Medline

Krashes MJ, Shah BP, Madara JC, Olson DP, Strochlic DE, Garfield AS, Vong L, Pei H, Watabe-Uchida M, Uchida N, Liberles SD, Lowell BB (2014) An excitatory paraventricular nucleus to AgRP neuron circuit that drives hunger. Nature 507:238-242. CrossRef Medline

Madisen L, Mao T, Koch H, Zhuo JM, Berenyi A, Fujisawa S, Hsu YW, Garcia AJ 3rd, Gu X, Zanella S, Kidney J, Gu H, Mao Y, Hooks BM, Boyden ES, Buzsáki G, Ramirez JM, Jones AR, Svoboda K, Han X, Turner EE, Zeng H (2012) A toolbox of Cre-dependent optogenetic transgenic mice for light-induced activation and silencing. Nat Neurosci 15:793-802. CrossRef Medline

Monzon ME, de Souza MM, Izquierdo LA, Izquierdo I, Barros DM, de Barioglio SR (1999) Melanin-concentrating hormone $(\mathrm{MCH})$ modifies memory retention in rats. Peptides 20:1517-1519. CrossRef Medline

Nahon JL, Presse F, Bittencourt JC, Sawchenko PE, Vale W (1989) The rat melanin-concentrating hormone messenger ribonucleic acid encodes multiple putative neuropeptides coexpressed in the dorsolateral hypothalamus. Endocrinology 125:2056-2065. CrossRef Medline

Onteniente B, Tago H, Kimura H, Maeda T (1986) Distribution of gammaaminobutyric acid-immunoreactive neurons in the septal region of the rat brain. J Comp Neurol 248:422-430. CrossRef Medline

Parkes D, Vale W (1992) Secretion of melanin-concentrating hormone and neuropeptide-EI from cultured rat hypothalamic cells. Endocrinology 131:1826-1831. CrossRef Medline

Petreanu L, Mao T, Sternson SM, Svoboda K (2009) The subcellular organization of neocortical excitatory connections. Nature 457:1142-1145. CrossRef Medline

Pissios P, Trombly DJ, Tzameli I, Maratos-Flier E (2003) Melaninconcentrating hormone receptor 1 activates extracellular signal-regulated kinase and synergizes with G(s)-coupled pathways. Endocrinology 144: 3514-3523. CrossRef Medline

Rao Y, Lu M, Ge F, Marsh DJ, Qian S, Wang AH, Picciotto MR, Gao XB (2008) Regulation of synaptic efficacy in hypocretin/orexin-containing neurons by melanin concentrating hormone in the lateral hypothalamus. J Neurosci 28:9101-9110. CrossRef Medline

Root DH, Mejias-Aponte CA, Zhang S, Wang HL, Hoffman AF, Lupica CR, Morales M (2014) Single rodent mesohabenular axons release glutamate and GABA. Nat Neurosci 17:1543-1551. CrossRef Medline

Roy M, David NK, Danao JV, Baribault H, Tian H, Giorgetti M (2006) Genetic inactivation of melanin-concentrating hormone receptor subtype 1 (MCHR1) in mice exerts anxiolytic-like behavioral effects. Neuropsychopharmacology 31:112-120. CrossRef Medline

Roy M, David N, Cueva M, Giorgetti M (2007) A study of the involvement of melanin-concentrating hormone receptor 1 (MCHR1) in murine models of depression. Biol Psychiatry 61:174-180. CrossRef Medline

Saito Y, Nothacker HP, Wang Z, Lin SH, Leslie F, Civelli O (1999) Molecular characterization of the melanin-concentrating-hormone receptor. Nature 400:265-269. CrossRef Medline

Schöne C, Apergis-Schoute J, Sakurai T, Adamantidis A, Burdakov D (2014) Coreleased orexin and glutamate evoke nonredundant spike outputs and computations in histamine neurons. Cell Rep 7:697-704. CrossRef Medline

Sears RM, Liu RJ, Narayanan NS, Sharf R, Yeckel MF, Laubach M, Aghajanian GK, DiLeone RJ (2010) Regulation of nucleus accumbens activity by the hypothalamic neuropeptide melanin-concentrating hormone. J Neurosci 30:8263-8273. CrossRef Medline

Sheehan TP, Chambers RA, Russell DS (2004) Regulation of affect by the lateral septum: implications for neuropsychiatry. Brain Res Brain Res Rev 46:71-117. CrossRef Medline

Sherwood A, Wosiski-Kuhn M, Nguyen T, Holland PC, Lakaye B, Adamantidis A, Johnson AW (2012) The role of melanin-concentrating hormone in conditioned reward learning. Eur J Neurosci 36:3126-3133. CrossRef Medline

Shimada M, Tritos NA, Lowell BB, Flier JS, Maratos-Flier E (1998) Mice lacking melanin-concentrating hormone are hypophagic and lean. Nature 396:670-674. CrossRef Medline

Staiger JF, Nürnberger F (1991) The efferent connections of the lateral septal nucleus in the guinea pig: intrinsic connectivity of the septum and projections to other telencephalic areas. Cell Tissue Res 264:415-426. CrossRef Medline

Tallent MK (2008) Presynaptic inhibition of glutamate release by neuropeptides: use-dependent synaptic modification. Results Probl Cell Differ 44:177-200. CrossRef Medline

Tritsch NX, Ding JB, Sabatini BL (2012) Dopaminergic neurons inhibit striatal output through non-canonical release of GABA. Nature 490:262-266. CrossRef Medline

van den Pol AN (2012) Neuropeptide transmission in brain circuits. Neuron 76:98-115. CrossRef Medline

Vong L, Ye C, Yang Z, Choi B, Chua S Jr, Lowell BB (2011) Leptin action on GABAergic neurons prevents obesity and reduces inhibitory tone to POMC neurons. Neuron 71:142-154. CrossRef Medline

Williams RH, Chee MJS, Kroeger D, Ferrari LL, Maratos-Flier E, Scammell TE, Arrigoni E (2014) Optogenetic mediated release of histamine reveals distal and autoregulatory mechanisms for controlling arousal. J Neurosci 34:6023-6029. CrossRef Medline

Wu M, Dumalska I, Morozova E, van den Pol A, Alreja M (2009) Melaninconcentrating hormone directly inhibits GnRH neurons and blocks kisspeptin activation, linking energy balance to reproduction. Proc Natl Acad Sci U S A 106:17217-17222. CrossRef Medline

Zheng H, Patterson LM, Morrison C, Banfield BW, Randall JA, Browning KN, Travagli RA, Berthoud HR (2005) Melanin concentrating hormone innervation of caudal brainstem areas involved in gastrointestinal functions and energy balance. Neuroscience 135:611-625. CrossRef Medline 